\title{
Remaking the dead, uncertainty and the torque of human materials in northern Zimbabwe
}

\author{
Joost Fontein
}

\section{Introduction}

In Zimbabwe the politics of heritage, memory and commemoration has been the subject of considerable academic and public debate for a long time. In March 2011, however, this took a decidedly macabre twist when reports, accompanied with graphic photographs and video footage, emerged of massive war veteran-led exhumations taking place at the disused Monkey William mine at Bembera Village in Chibondo in Mount Darwin (northern Zimbabwe), where the remains of hundreds, if not thousands of people apparently killed by the Smith regime during the liberation war of the 1970s, had been (re)'discovered'. These events attracted enormous media attention and an unprecedented furore of angry responses from different political parties, civil society organisations, human rights groups and public commentators within Zimbabwe. The criticisms that these grisly exhumations provoked offer key insight into the topography of Zimbabwe's complex 'politics of the dead', and the difficult questions that can arise about who has sovereignty over human remains. But apart from the grotesque displays of human remains involved, and the crude politicking taking place around them by the war veteran group, the Fallen Heroes Trust (FHT), which is closely linked to the ruling party, ZANU-PF (Zimbabwe African National Union Patriotic Front), and which used the exhumations to reinforce its anti-colonialist rhetoric of 'patriotic history' (Ranger 2004; Tendi 
2010), perhaps the most striking aspect of these events was the way in which the forms and qualities of the human materials themselves animated the heated debates that ensued.

Many objections stressed the 'unscientific', 'chaotic' and 'destructive' nature of the exhumations. They were decidedly 'unforensic', and led by war veterans and spirit mediums who stressed 'African' ways of dealing with the dead, as they paraded villagers, reporters and TV crews through the mine, and past tangled piles of indistinct human remains materials laid out on plastic sheets, to illustrate the horrors inflicted by Rhodesians. But the nature of the materials themselves caused many to question the true identity of the people whose remains were re-emerging from the abandoned mine. Did they really date from the late 1970s? If so, why were some of the remains still apparently fleshy, leaky and stinking? Might they include more recent human remains - from the gukurahundi massacres of the 1980s; or ZANLA (Zimbabwe National Liberation Army) purges of ZIPRA (Zimbabwe People's Revolutionary Army) comrades around independence; or from more recent political violence against MDC (Movement for Democratic Change) supporters since $1999 ;^{1}$ or even the missing bodies of military purges at the Chiadzwa diamond fields in 2008/9?

In this chapter I explore how these questions about the identity of the dead, the manner of their deaths and who has sovereignty over them - i.e. by whom and how they should be exhumed and reburied - were provoked by the excessive potentialities of the properties of the human substances being exhumed; by their profoundly evocative and affective, yet unstable, uncertain and ultimately indeterminate materialities. It focuses on how the mass of stinking, intermingling, leaky, half-decaying bodies and bodily substances being disinterred and separated - being remade imperfectly and contingently into particular kinds of 'political bodies/subjects' - both demand and enable, and yet ultimately defy the very reconstitution of the dead and past lives, and the complex politics of commemoration in which they are entangled.

It is likely that some in ZANU-PF saw the political usefulness of the uncertainties provoked by the excessive potentiality of the human materials being exhumed from the Mount Darwin mines. They could both celebrate their 'liberation heroes' and reinforce the anti-colonialist rhetoric through which they have very effectively polarised Zimbabwean politics and marginalised opposition political parties, NGOs and human rights organisations in the last decade and, at the same time, demonstrate and remind Zimbabweans of 
their own capacities for violence. In this way the exhumations can be understood as part and parcel of ZANU-PF's performative stylistics of power. Yet ultimately the uncontained uncertainties about the identities of the dead, and the manner of their deaths, in part provoked by the indeterminate nature of the human materials, were unsustainable. By August 2011 the exhumations had been stopped, the mines sealed and exhumed remains reburied at the site, and the issue largely disappeared from the new agenda, as the government became increasingly concerned that the matter had got 'out of hand', and sought to physically and discursively contain the issue and any political ramifications that may ensue.

If the huge resurgence of scholarly interest in the politics of death and 'the dead' over the last decade, in Africa (Lee and Vaughan 2008) and elsewhere (Verdery 1999), has increasingly recognised that beyond both biopolitics and necropolitics (Mbembe 2003) the transforming materialities of bodies and lives matter (see Jindra and Noret 2011; Krmpotich, Fontein and Harries 2010; Posel and Gupta 2009), then the Mount Darwin exhumations and the responses they provoked illustrate how human remains can exemplify the excessive potentialities of stuff - what Chris Pinney has called 'the torque of materiality' - and how the 'alterity of an enfleshed world' defies any easy reading and therefore makes possible the very politics of uncertainty and (un)becoming in which they are entwined (Pinney 2005: 270).

\section{Context: the politics of the dead in Zimbabwe}

As the complex entanglement of the politics of the past, and of the dead, with that of its material remains, performative practices and monumentalised forms (funerals, state commemoration, monuments, ruins, artefacts, graves, bodies, bones and so on) have received renewed scholarly attention in recent years, the significance of human corporeality, or 'carnal fetishism' as Bernault (2010) calls it, has increasingly come into focus (Jindra and Noret 2011; Krmpotich, Fontein and Harries 2010; Lee and Vaughan 2008; Mbembe 2003; Posel and Gupta 2009). In Zimbabwe, where the politics of heritage, memory and commemoration has been the subject of much academic and public debate for some time, this emergent conjunction of meaning and matter has followed a broadly similar trajectory. After independence in 1980, the historiography and commemoration of the liberation struggle became the subject of 
profound (and continuing) contestation. Since 2000, this politicisation of the historiography of the liberation struggle has intensified through the emergence of what Ranger (2004) has called 'patriotic history'. ZANU-PF has increasingly arrogated exclusively to itself the liberation credentials and 'languages of suffering' through which it has polarised political debates, and effectively marginalised the various factions of the opposition MDC, with which it was forced to share power in Zimbabwe's hugely problematic 'unity government' from 2009, until its recent 'landslide' win in the elections of July 2013 enabled it to once again become the sole ruling party.

While this 'patriotic history' has manifest itself in many guises, a central dynamic has circulated around what Muchemwa calls ZANU-PF's 'necropolitan imagination' and 'an aesthetics of heroism' (2010). This is apparent both through the ever heightening contestations surrounding the highly partisan ZANU-PF-dominated selection of National Heroes (Fontein 2009a; Kriger 1995; Werbner 1998), but also by a host of new state-driven oral history and heritage projects focusing on the legacy of the struggle; in particular the enthusiastic adoption of the SADC-wide, UNESCO-sponsored 'liberation heritage' project by National Museums and Monuments of Zimbabwe (NMMZ), through which this parastatal has become increasingly involved in state commemoration and has carried out excavations, exhumations and reburials at former guerrilla camps in Mozambique, Zambia and other former frontline states.

Elsewhere (Fontein 2009a) I have argued that this 'liberation heritage' project not only matched ZANU-PF's rhetoric of 'patriotic history' with NMMZ's need for state funding. It was also a response to long-standing demands from the war veterans, spirit mediums and relatives of the war dead, and even the unsettled, troubling spirits of the dead themselves, for the return of human remains buried in anonymous, shallow and sometimes mass graves across Zimbabwe's rural areas, and in former guerrilla camps in neighbouring countries. Indeed in the last decade there has been a proliferation of such demands, reflecting both the changing salience of human corporeality across the region and beyond, and a complexity of diverse local interests and agendas that do not always perfectly match the political imperatives and rhetoric of 'patriotic history' espoused by ZANUPF's ideologues; from war veterans and families haunted by the unsettled spirits of their dead, to spirit mediums concerned about the failure of the rains, ancestral anger and the state of the nation as a whole, to land settlers seeking to re-establish 'autochthony' on resettled ancestral lands (Fontein 2011). 
In many cases exhumations have already been taking place, often without official permission, or beyond the supervision of trained archaeologists from NMMZ or forensic scientists. In January 2008, for example, long before the dramatic events at Chibondo exploded into the public arena in March 2011, the FHT and a related war veteran-led group Taurai Zvehondo [lit. 'Talk about the war'] were already involved in identifying mass graves in Mount Darwin, and were 'awaiting assistance from the Government which should lead the exhumation process.' ${ }^{2}$ There are also many cases of unidentified human remains resurfacing from unknown graves and abandoned mineshafts dating back to the 1970s. Numerous newspaper reports over recent years attest to this fairly common occurrence, which long predates the recent (re)discovery of the human remains in the mineshafts at Chibondo. ${ }^{3}$ In a sense, such activities and discoveries have obliged government institutions to act, and in this context NMMZ's adoption of its 'liberation heritage' portfolio in the late 1990 s can, in part, be understood as a response to the demands of relatives and living comrades, and even the resurfacing bones and unsettled spirits themselves (Fontein 2009a). Certainly NMMZ's 'liberation heritage' activities have often appeared reactive to events already taking place, as indeed was the case with the Chibondo exhumations that I discuss below.

The issue of the return of the war dead has animated highly politicised debates about state commemoration in Zimbabwe since independence (Daneel 1995; Kriger 1995; Werbner 1998). Although some limited official reburials were carried out in the 1980s and 1990s (see Daneel 1995; Kriger 1995), demands for such events intensified as Zimbabwe's political and economic situation worsened dramatically after the end of the 1990s. In 2001 Ambuya VaZarira, an influential spirit medium in Masvingo district, explained how war veterans frequently 'come to me here, telling me that ... their fellow comrades who died in Mozambique are continuously giving them problems, harassing them, saying that they should be collected from Mozambique ... so the masvikiro [spirit mediums] ... agreed that we ... will see how they can collect these dead from Mozambique.' ${ }^{4}$ These comments echoed common concerns shared by many war veterans and families haunted by the spirits of the unsettled war dead, yearning to return to the soil of their ancestors to become ancestors themselves, so that they in turn can look after their living descendants.

Such concerns reflect the importance of 'bringing home' rituals, held a year or more after death and a funeral, to return the spirits of the deceased home from a liminal period in 'the bush' to 
become benevolent ancestors - kugadzira in Shona or umbuyiso in siNdebele - which is well known across Zimbabwe. Failure to perform these rites leaves the deceased unsettled and incomplete in their transformation into ancestors. Where the location of graves is unknown or where proper funeral rites have not taken place the deceased can become dangerous and frightening spirits known as ngozi [Shona and Ndebele], who haunt the people responsible for their deaths, but also their living relatives and friends (Bourdillon 1987: 233-5; Werbner 1991: 151-6, 188-90). These unhappy spirits also haunt the 'nation' as a whole, as indeed spirit mediums told war veteran leader Andrew Ndlovu in 2001. ${ }^{5}$ Spirit mediums often complain that droughts, economic crises, and even the AIDS pandemic, are all the result of these unhappy spirits demanding to be returned home. Their troubling presence equally intertwines with the politics of regionalism, 'traditional authority' and factional disputes between rival war veteran groups.

However, Zimbabwe's social and political milieu is also haunted by the victims of postcolonial violence. This primarily takes two forms. Firstly, and most recently, the escalating political violence by ZANU-PF against opposition MDC supporters and civil society activists since 2000, and particularly during the 2008 elections (see for example Masunungure 2009; Solidarity Peace Trust 2008a), has manifested its own 'politics of the dead' in the form of tortured, dismembered bodies, disappearances, disrupted funerals, avenging spirits and alternative MDC registers of 'heroes', which I have discussed in greater detail elsewhere (2010). Secondly, perhaps even more contentious than the tortured bodies of political violence in the last decade, there have been the unsettled spirits and resurfacing bones of the gukurahundi massacres in Matabeleland and the Midlands in the 1980s, when an estimated 20,000 civilians were killed by the notorious fifth brigade during a reign of terror directed by the ruling ZANU-PF against its minority rival ZAPU, under the guise of rooting out ZAPU 'dissidents' (Alexander et al. 2000; Eppel 2001, 2004, 2009; Ranger 1999; Werbner 1991). This lasted from 1982 until 1987, when ZAPU was 'swallowed' into the unity pact with ZANU-PF, and remains a massive scar on Zimbabwe's postcolonial milieu and a hugely sensitive topic. Community efforts to commemorate, rehabilitate, exhume and rebury gukurahundi victims in order to resolve deep legacies of violence among the living and the dead were long obstructed by ZANU-PF.

The profound and deepening salience of the unresolved legacies of the gukurahundi terror are reflected by the rapidly growing 
number of calls in recent years for the issue to be addressed. Yet the legacies of the gukurahundi continue to fester, perhaps more so than ever. ${ }^{6}$ Although some gukurahundi sites are known, many families and communities in Matabeleland continue to complain that their lives are deeply impaired and haunted by the unsettled spirits of the gukurahundi dead and the unresolved violence of the 1980s (Eppel 2001; Werbner 1991), and, as with the mass graves of the liberation struggle, gukurahundi bones and graves are still being discovered. ${ }^{7}$

Clearly then, the politics of the dead in Zimbabwe long predates the grisly events at Chibondo that burst into the public arena in March 2011. It is deeply animated both by the bones of past massacres resurfacing from shallow mass graves around the country and across international borders, and by the tortured bodies of recent political violence. Moreover this politics of the dead is deeply animated by the spirits of the dead themselves, as deeply frightening ngozi spirits, whose presence is intimately intertwined with the 'affective presence' and 'emotive materiality' of bones, bodies and human substances (Fontein 2010). These are linked through the simultaneously symbolic and material processes whereby people, living and dead, are properly constituted, and the proper ritual and material processes through which people are made safely dead. In this respect the resurfacing bones of people killed in the war or during the 1980s, the leaky, tortured bodies and disrupted funerals of people killed much more recently and the frightening presence of the unsettled dead as ngozi spirits, all reveal the transgression of normal and normalising processes whereby people (living and dead) are constituted, and the living transformed into benevolent ancestors, and sometimes avenging spirits. And it is in this context that exhumations and reburials are often understood, across very different registers of meaning and practice (e.g. Crossland 2009; Eppel 2001; Renshaw 2010), as forms of healing or commemoration - a way to make people safely dead, or in other words, to 'feed' (Rowlands 1999: 144), 'atone for' or 'finish the work of' the dead (Kuchler 1999: 55).

Yet even where there is general agreement about the socially cathartic potential of exhumations, these are processes that can be unusually problematic (see Renshaw 2010) and enormously contested, as was illustrated by the Chibondo events, which I turn to below. This is particularly the case where the identity of the dead and the manner of their deaths are uncertain. In the exhumations of mass graves at Chimoio, Nyadzonia, Freedom camp and other former guerrilla camps in Zambia and Mozambique, the political identity of the dead and the manner of their deaths were hardly in dispute, even 
if old and new rivalries and tensions inevitably sometimes emerged between different actors involved. The Chibondo exhumations were very different in this respect. There the ambivalent materialities of the human remains being disinterred, and shown widely in television and newspaper reports, provoked profound uncertainties and controversy about the identity of the dead and the manner of their deaths, and this meant that tensions between different ways of reconstituting the past and remaking the dead came to fore.

\section{The Chibondo exhumations}

Almost as soon as the discovery and exhumations of human remains at Chibondo were announced in March 2011, they became mired in controversies that reflected the politics of the dead I have been describing. Like state commemoration in the 1980s and 1990s, initial concerns circulated around the highly politicised and partisan nature of the exhumations. The enormous attention the exhumations received from the state-controlled, ZANU-PF-aligned print and broadcast media fed claims that this was an exercise in ZANU-PF propaganda, in the face of waning popularity, worsening internal factionalism and possible forthcoming elections. ${ }^{8}$ As ZANU-PF politicians publicly visited the site, many such criticisms focused on the deeply disturbing images and video clips of disassembled, decaying bodies, bones and undefined human remains being crudely disinterred and chaotically laid out on plastic sheets, broadcast several times a day, like ZANU-PF election jingles, on televisions across the country.

Yet even as such critiques of ZANU-PF's 'gross politicisation' of the exhumations were appearing in independent newspapers and websites, the ZANU-PF-aligned media was describing in detail, and extolling the virtues of, the war veteran- and spirit medium-led tours being conducted at the site for people, including school children, bussed to Chibondo from all over the country. Claims were made in April that they were receiving 'between 1,500 and 3,000 visitors a day,', and recent fieldwork in Masvingo suggests that ZANU-PF officials across Zimbabwe's different regions were mobilising high-profile visits to Chibondo for local chiefs, war veterans, spirit mediums and other 'traditional' rural leaders. It is also clear that such visits were carefully choreographed, and that 'the war veterans ... wanted journalists to interview people they had selected themselves so that they wouldn't "give out the wrong information". ${ }^{10}$ Journalists visiting the 
site reported that 'Zanu PF slogans and songs were the order of the day' and that 'school children, teachers and villagers were forced to go underground and view the bodies so that they would appreciate the extent of the brutalities of the Rhodesian Army'.

Many commentators recognised that the politicisation of these human remains by ZANU-PF fitted a long-established pattern of using a narrow and exclusivist legacy of the liberation struggle to buttress its own legitimacy. This includes undermining that of opposition parties, including 'old' (and 'new') ZAPU, the fractious factions of the MDC with whom it was then sharing a 'unity government', and, more recently, a host of emergent Ndebele pressure groups such as the Mwthazi Liberation Front (MLF), a radical group agitating for secession for Matabeleland. It is not surprising therefore that the crude politicking at Chibondo provoked the anger of those linked to ZAPU and ZIPRA, who have long felt that their contributions to the liberation of Zimbabwe have been deliberately ignored.

The spectacle of the Chibondo exhumations also quickly provoked wider sensibilities about the unresolved legacies of the gukurahundi, and very soon ZAPU and other Matabeleland-based pressure groups were calling for other mass graves from the gukurahundi period to be similarly excavated and their human remains exhumed and 'given a decent burial.'

Apart from the still unresolved gukurahundi legacies, the Chibondo exhumations also raised questions about the fate of much more recent victims of postcolonial violence. The political commentator John Makumbe asked, rhetorically, 'when will the group that is doing this work visit Domboshava to exhume the bodies of several soldiers that that were "buried" there by night only a few years ago?'. ${ }^{11}$ Similarly in a press statement on 24 March, the largest MDC party (MDC T) stated that:

The MDC ... welcomes the exhumation, identification and proper documentation of any Zimbabwean whose fate was determined by the liberation struggle - a national project in which we all took part. For the exercise that is above party and sectional selfishness, a national budget administered by the relevant state institutions, led by the Ministry of Home Affairs, is imperative to cover the necessary costs of tracking down the genealogy and family trees of the victims through forensic science, carbon dating and indisputable DNA sampling. Such a process would reveal death details and murder methods. Zimbabweans have endured violence since colonialism and yearn for the day when the truth about the liberation war, Gukurahundi, Operation Murambatsvina, the 2008 atrocities -among others - is brought onto the surface for informed debate and reflection. Without such a concerted, nationally sensitive process, 
national healing and reconciliation shall be impossible. The MDC calls on ZANU PF to stop what it is doing and leave it to the nation to work out an appropriate way forward, beyond amateur propaganda antics and political carelessness. ${ }^{12}$

This statement illustrates how quickly concerns were raised about the manner of the exhumations themselves. These kinds of critiques focused on the crude, unsophisticated way in which the exhumations appeared to be handled, and the absence of any trained 'archaeologists, pathologists or other specialists' supervising the events. ${ }^{13}$ The widely circulated images of war veteran exhumers in overalls and gum boots pilling up unsorted human remains on plastic sheets caused huge consternation about the lack of forensic expertise at the site.

In their defence FHT emphasised their use of spirit mediums and diviners to enable them to identify the dead and return their remains to their families. For them this was not a new practice. ${ }^{14}$ Given the long salience of the haunting, unsettled dead that I have discussed, it is not surprising that FHT spokesmen placed a great deal of emphasis upon the resolution of suffering for communities and families and especially the dead themselves, which their exhumations at Chibondo offered. Official reports emphasised the evidence of Rhodesian atrocities that was being unearthed with the human remains, including accounts of people being buried alive, the use of acid to destroy corpses and live grenades being found amidst the mangled human materials. ${ }^{15}$ Such accounts linked evidence of Rhodesian atrocities being revealed to the resolution offered by 'traditional' 'African' approaches to the identification of the dead that were being applied, which some argued meant that forensic approaches would not be necessary. Saviour Kasukuwere, ZANU-PF 'minister for black empowerment', stated 'Forensic tests and DNA analysis of the remains won't be carried out ... Instead, traditional African religious figures will perform rites to invoke spirits that will identify the dead.' 'Spirits of the dead had long "possessed" villagers and children in the district', he added; they have 'refused to lie still. They want the world to see what Smith did to our people. These spirits will show the way it's to be done. ${ }^{16}$

Nevertheless, the crude and decidedly unforensic nature of the exhumations did raise wider disquiet about 'disrespecting the dead'. Such concerns fed into a high court application made in Bulawayo at the beginning of April 2011 by lawyers acting for ZIPRA veterans to 'stop the government from going ahead with its controversial programme of exhuming mass graves. ${ }^{17}$ The high court order was successful and by 
7 April Justice Nicholas Mathonsi had 'granted an interdict sought by the Zimbabwe People's Liberation Army (ZIPRA) war heroes who are demanding that any exhumations in Mt Darwin ... should be carried out in a government-led "legal process"'.18

Despite the claims of people involved with the FHT exhumations, about there being no need for forensic expertise, it seems that others in ZANU-PF and government did quickly recognise the need to legitimise the exhumations by bringing in professional archaeologists from NMMZ. If early on NMMZ had denied any involvement, on 27 March (before the high court's decision), ZANU-PF's co-minister of home affairs, Kembo Mohadi, announced that 'the government was taking over the exhumations from the Fallen Heroes Trust. ${ }^{19}$ Media politicking around the site continued however, but by May it was clear that no new exhumations were taking place at Chibondo, and as security around the site was increased, efforts were now focused on what to do with the 848 sets of remains that had already been disinterred.

By this stage NMMZ was already involved in efforts to rebury the remains in a new, memorialised grave at the site. On 13 August The Herald reported that the 'reburial of over 700 former liberation fighters that were buried at the disused mine shafts at Chibondo' had begun. Minister Kasukuwere said he hoped the area 'would become a national shrine' and that 'the process should remind Zimbabweans of the cruelty of the Ian Smith regime', and noted, 'over 24,000 people [had] visited the site since the exhumations started: ${ }^{20}$

In many ways, then, the highly visible but crudely performed politics of the dead taking place at Chibondo mirrored and exacerbated the long-existing tensions of commemoration in Zimbabwe: the narrow celebration of ZANU-PF heroes, the marginalisation of other nationalist contributions, and the belated efforts to legitimise the operations through NMMZ's liberation heritage portfolio, as well as of course ZANU-PF's continuing reticence about confronting its terrible gukurahundi legacy, or dealing with the dead of other periods of postcolonial violence in which it is implicated. Importantly, however, these kinds of criticisms did not really question the need for the exhumations per se, nor initially the identity of the remains being exhumed. But this would change.

\section{Too 'fresh', 'intact', fleshy, leaky and stinky?}

As ZANU-PF's publicity machine went into overdrive, using the exhumations to inflate its anti-colonialist rhetoric, controversies 
surrounding the events quickly took on a much more sensitive dimension, which turned on the nature of the human materials themselves. Amid the proliferation of TV and press coverage, serious questions were raised about the true age and identity of the remains, and the cause of their deaths. Many reports suggested that the distorted bodies and disassembled remains, being chaotically disinterred, laid out on plastic and broadcast on television, were simply too 'intact', leaky, fleshy and too smelly to date back over thirty years to the liberation struggle. The Standard reported that suspicions were 'aroused' after 'journalists ... were shocked to see bodies that were still intact'. 'One of the bodies still had visible hair, while others had their clothes intact', the report continued, and another 'had fluids dripping from it', and a 'strong stench still permeates the 15-metre-deep mine shaft. ${ }^{21}$ An unidentified pathologist claimed that 'there was no way there could still be a stench ... three decades after the bodies were allegedly dumped ... ordinarily by this time there should only be bone-remains', and numerous other news reports too carried articles citing pathologists claiming that the visual evidence of the Chibondo remains suggested they included 'fresh bodies. ${ }^{22}$

It was not just the human remains that provoked this profound uncertainty but also the objects and artefacts associated with them: particularly the clothes, shoes and uniforms that were found entangled with the remains. Even Ambuya VaZarira and her son Peter Manyuki (who were bussed there from Masvingo by ZANU-PF officials) were shocked that 'some of these bodies were still wearing their clothes'. 'Is it possible that bodies would still be wearing clothes after 30 years?', Peter asked me rhetorically (Fieldnotes, 13 December 2011). Some reports even suggested that cell phones, coins and (recent) plastic ID cards had been found among the remains, and in Bulawayo I heard rumours that Mafela Trust officials visiting the mine found Zimbabwe National Army ID tags among the remains (Fieldnotes, 6 December 2011). Of course the FHT dismissed as 'mischievous' and 'sad indeed' such claims that the bodies were 'too fresh' to date to the liberation struggle. ${ }^{23}$ But interestingly they too pointed to the clothes, uniforms and other artefacts found in the mine to support their argument that these were victims of Rhodesian atrocities. In particular, a great emphasis was placed on the 'Super-pro' canvas shoes found among the remains, which were very commonly worn by guerrilla fighters during the struggle. For people on both sides of the controversies that the exhumations provoked, the artefacts around them seemed sometimes to offer more stability of meaning than the remains themselves. 
For her part, Shari Eppel of the Solidarity Peace Trust was very careful to point out that what may appear like 'fresh', still decomposing flesh may actually be 'mummified' remains dating back to the 1970s. This is an effect that is, apparently, not uncommon in mass graves, where many bodies have been densely buried on top of one another. Nevertheless she also acknowledged that it is not impossible that these graves contained victims from the 1980s. ${ }^{24}$ But her main argument emphasised that the uncertainty surrounding the material qualities of the remains could be resolved and determined only by professional forensic anthropologists.

These uncertainties about the age and identity of the Chibondo dead and the manner of their deaths raised highly emotive concerns about whether these Chibondo remains themselves might include not only victims of Rhodesian violence, but also victims of more recent ZANU-PF violence. Were these ZANU-PF heroes or victims? Peter Manyuki, who was bussed to Chibondo to witness the exhumation, expressed a common opinion when he said that 'probably there are bodies from the liberation struggle there, but maybe also bodies from other periods of violence, like from the gukurahundi, and maybe the elections of recent years, and even from Chaidzwa ... there are many periods in Zimbabwe's recent past when parents lost their children and don't know where they are buried' (Fieldnotes, 13 December 2011).

Very quickly all the different constituencies of Zimbabwe's 'politics of the dead' began suggesting that the Chibondo remains included 'their dead', including the MDC parties, ZAPU and ZIPRA veterans, Mafela Trust and the radical new Ndebele groups such as the MLF. Indeed the MLF were first to suggest that the Chibondo remains included gukurahundi victims, stressing that 'thousands mysteriously "disappeared" in Harare, Chitungwisa and other parts of Mashonaland at the hands of the tribalistic Zimbabwe regime', and adding that 'the "discovery" of the said skeletons could as well provide a clue as to the fate of the said ethnic Ndebele people and ex-ZIPRA force troops who disappeared during the same period. ${ }^{25}$ Soon ZAPU, ex-ZIPRA veterans and others followed suit. ${ }^{26}$ The then prime minster and MDC president, Morgan Tsvangirai, 'slammed' the exhumations, and MDC deputy spokesman Chihwayi claimed these bodies look fresh; ZANU-PF should come clean on the issue of these exhumations ... those remains are of MDC who were killed by ZANU-PF [since] 2000 and especially during the run-off elections of 2008.27 Amid all these suggestions about who the remains might include, some even suggested that the Mount Darwin mines 
contained very recent victims of the army's violent take-over of the Chiadzwa diamond fields in late 2008 and early 2009, when it is alleged hundreds of illegal diamond miners and traders were machine-gunned from helicopters. ${ }^{28}$

No longer just deeply 'disrespectful to the dead', the exhumations were now criticised as being a deliberate attempt to destroy or 'cover up' crucial evidence of violence and murder. Certainly people questioned whether Chibondo was a 'war grave' or a 'crime scene', and for many using divination and spirit possession was no longer an acceptable means of identifying and settling the dead, but a deliberate obfuscation of the 'truth' about the dead; a way as Eppel put it of 'silencing the bones. ${ }^{29}$ In response the FHT complained that Tsvangirai's criticism of the exhumations was not 'in defence of African culture' and that he was 'talking cheap politics. ${ }^{30}$ Nevertheless the uncertain nature of the human materials being exhumed had changed the focus of the controversies, from the crude politicisation and 'disrespectful' nature of FHT practices, to much more sensitive questions about the 'true' identity of the Chibondo remains, and the 'real' purpose of the decidedly 'unforensic' exhumations. Having initially argued that similar exhumations should take place at other mass graves around the country, ZIPRA veterans, the MDC and other critics quickly changed their focus towards the prevention of any exhumations without proper forensic expertise.

Clearly the exhumations at Chibondo had indeed raised far 'more questions than answers, ${ }^{31}$ and perhaps this offers the best explanation for why, after initially supporting the war veteran efforts with enormous media coverage and aplomb, ZANU-PF ministers in the 'unity government' quickly moved in to 'take over' and then to rapidly close them down. It also explains why, as the controversies deepened, the FHT became increasingly concerned to 'choreograph' visits to and reporting at the site, and why once the government and NMMZ had taken over, security at the site was intensified and public visits stopped. It also explains why the question of professional, forensic involvement came to dominate the debates that ensued, even though both those involved with FHT at Chibondo and those who were opposed to them espoused the potentially cathartic, 'healing' nature of exhumations and reburials. Suddenly questions about how human remains are remade into dead (political) subjects, how the dead are made present and how the past is reconstituted - how the cause and manner of these deaths was to become known - became of central concern. And these sensitive and difficult questions turned, ultimately, on the indeterminate nature of the materials, substances, 
things - human and non-human - being reconstituted into particular kinds of subjects and objects. These are questions that were raised, in part, by the indeterminate yet demanding and excessive potentiality of human materials themselves.

\section{The torque of materiality and the excessive potentiality of human remains}

Elsewhere I have begun to examine Zimbabwe's politics of the dead (Fontein 2009a, 2010, 2011) through analytical lenses emergent from recent theoretical debates about materiality (Miller 2005), affect (Navaro-Yashin 2009), the 'agency of objects' (Gell 1998; Latour 1999; Leach 2007) and the 'imbrication of the semiotic and the material' (Deleuze and Guattari 1987: 337); what Domańska has called a 'return to things' (2006). What bones do in Zimbabwe is not confined to questions about contested representations of the past, or the 'symbolic efficacy' of bodies (Verdery 1999), but also relates their 'emotive materiality' as human substances, and their 'affective presence' as dead persons who continue to make demands upon society. So bones and indeed bodies in Zimbabwe have an ambivalent agency as uneasy subject/objects, both as extensions of the dead themselves (Gell 1998), as restless and demanding spirit subjects/persons, but also as unconscious 'objects'/'things' (Latour 1999) that retort to and provoke responses from the living. The two are often intertwined, so that the emotive materiality of human corporeality is often finely entangled with the affective presence of the dead as spirits demanding recognition, atonement, 'feeding' (Rowlands 1999) and proper 'ritual', symbolic and material transformation into ancestors. ${ }^{32}$

The significance of the simultaneously material and symbolic transformations and transferences involved in funeral processes exemplifies the importance of Ingold's critique of 'materiality' and 'object agency', in favour of thorough investigation into the properties, flows and transformations of materials (2007: 1-2). This is pertinent to understanding how the political efficacy of recently tortured bodies relates to that of older resurfacing bones in Zimbabwe, by suggesting that what matters is not necessarily objects like bones, 'the body', 'graves' or indeed the soil, but rather the properties and flows of materials between them. It illustrates how ritual and material transformations (and transgressions thereof) of fleshy, leaky bodies into dry bones, and people into ancestors, through the merging of bodily substances into soil - how the living become (safely) 
dead - can animate the politics of the burial and belonging in Zimbabwe (Fontein 2011). It also shows how violence against living people (which interferes with bodily boundaries and the material 'containment' and constitution of persons) is finely related to disruptions of funerals, the dumping of corpses and the subsequent resurfacing and return of their remains and avenging spirits, illustrating how Zimbabwe's politics of the dead involves not only contested commemorations of people killed in the past, but also continuing violence against the living (Fontein 2010).

The determination to focus on materials and substances also reverts attention back to how materials become, or are stabilised (or for Latour are 'purified') into 'objects' and indeed 'subjects', physically but also conceptually, historically and politically. How do bones - or fragments of bone sifted from the merged substances of decayed bodies, sand and soil - become recognised, 'articulated' (Hallam 2010), or (re)constituted as uneasy human/things or ambivalent subject/objects, through archaeological excavation, forensic exhumation or indeed divination? And how, in turn, are these processes turned into commemorative rituals or funerals, not only responding to the demands of the (reconstituted) dead, but actually 'remaking' them? Ingold's focus on materials (2007), and 'things' (2009) commands us to consider how exhumations are, in part, about remaking or reconstituting 'the dead' as particular kinds of 'objects' or 'political subjects', 'afforded' or enabled by the materials excavated from mass graves, an issue that others have explored in greater depth (Crossland 2009; Filippucci et al. 2012; Hallam 2010; Renshaw 2010). Thus, Filippucci et al. (2012: 199) have described 'unearthing' human remains as:

[A] transformative and relational process of becoming, involving soil, hands, towels and brushes, and bones ... through which the flow of human materials with other substances is arrested and channelled, so that human remains are temporarily stabilized into recognizable objects and the work of cultural elaboration can begin. ... it is a process of becoming by which traces of past lives are reconstituted and come to assert an ambivalent quality of felt presence, which has the capacity to unsettle the here and now, with an indeterminate alterity.

Importantly this emphasis on becoming or 'remaking of the dead' points to the 'otherness of human remains' (Renshaw 2010: 460); how 'things, materials and stuff are always both more and less than the objects and subjects that they constitute, substantive qualities that are in excess of, yet imbricated in their own becomings and unbecomings' (Filippucci et al. 2012: 11; Fontein 2011: 718). Pinney 
calls this the 'alterity (or torque) of materiality that can never be assimilated to a disembodied "linguistic-philosophical closure" (2005: 270). If scholars of 'materiality' have often stressed the 'dialectics of objectification' (Miller 2005: 38), then for Pinney 'the dialectic of "subjects making objects making subjects" ... is not smooth but instead rife with disjunctures and fractures' (Filippucci et al. 2012: 204) exactly because stuff, substances and things always maintain an excessive potentiality to exceed their constitution, 'stabilisation' or 'purification' into recognisable objects or identifiable subjects. Pinney's insistence upon the 'enfleshed alterity' of the material world means that processes of becoming, stabilisation or (re)constitution are fraught, incomplete, uncertain and ultimately indeterminate. It is this indeterminacy that can make them so contested.

This 'indeterminate alterity' of things or 'torque of materiality' indicates that the uncertainty that surrounds how and what human remains do in Zimbabwe's politics of the dead pre-exists or is immanent to questions about the ambivalent agency of bones and bodies as uneasy subject/objects. Furthermore it raises important questions about what, then, is specific or unique about human substances that sets them apart from other kinds of things or materials. Filippucci et al. (2012) suggest that the distinction between metaphor and metonym might be useful here: 'if initially human remains appear poignant because they seem more obviously "human" than other material objects and artifacts, then at second glance this poignancy does not easily or clearly make them more communicative as metaphors or objectifications of human beings or past lives lived' (Filippucci et al. 2012: 211; see also Renshaw 2010). Rather human remains often 'signal presence more than meaning' and these 'excessive metonymic qualities defy, perhaps much more than other things, efforts to turn them into meaningful metaphors'. 'As a result', they continue: 'they can be subject to huge and often highly specialised efforts and dramatic over determinations into particular types of subjects/objects, such as ancestors, victims, heroes or specimens - processes that are often unusually problematic, politicized and contested' (Filippucci et al. 2012: 211).

This reveals how the controversies surrounding the Chibondo exhumations were provoked by the excessive potentialities of the human substances being exhumed - by their profoundly evocative and affective yet unstable, uncertain and ultimately indeterminate materialities. It also explains why the objects and artefacts - the clothes, uniforms, shoes, coins, grenades and so on - found with the tangled mass of stinking human substances took on such importance 
for the different sides of the debates that ensued: because they offered more stability of meaning (see Renshaw 2010). Furthermore it explains why many of the debates turned on the manner of the exhumations, particularly between demands for 'proper' forensic expertise and FHT's emphasis on 'African' ways of dealing with the dead, even as everyone agreed that exhumations and reburials can be cathartic, and offer resolution and 'healing'.

Indeed this 'torque of materiality' and the 'excessive metonymic qualities' of human remains suggest that neither of these approaches is necessarily very good at 'remaking the dead', in the absence of extensive contextual work by which human substances can be meaningfully reconstituted as specific kinds of political subjects, and even particular named individuals (whether through oral history, DNA analysis, the archaeology of material context or performances of social relatedness by which divination and spirit possession achieve moral authority). Ultimately, then, the excessive potentiality of human materials makes the 'remaking of the dead', however approached, a profoundly uncertain and indeterminate process, and it is this quality that often leads to highly 'specialized efforts and dramatic over determinations', which, as the Chibondo exhumations exemplified, can be 'unusually problematic, politicized and contested'.

\section{The politics of uncertainty}

This argument about the 'indeterminate alterity' and 'excessive potentiality' of human remains provides explanation for the fierce controversies that surrounded the Chibondo exhumations. One issue remains to be explored, however. Although the uncertainties about the identity of Chibondo dead provoked by the indeterminacy of the human remains animated the most effective critiques of ZANU-PF efforts to 'remake the dead' into their liberation heroes, there is also a sense that these profound uncertainties may have had (at least for a short time) some recognised political utility.

If politics is often assumed to turn upon the (contested) work of determination, and the elimination of doubt, then recent work in political anthropology suggests that uncertainty can also be part of a performative stylistics of power. 'Uncertainty' has become something of a new 'buzz word' in anthropology of late; it is, if you like, the new 'ambiguity'. Analytical uses of the term have been diverse (see Buyandelgeriyn 2008), but my usage here is very specific. Can 
we relate the uncertainties and indeterminacies of stuff and material substance to the productive duplicities and uncertainties that often surround rumours, gossip and political satire, which, as Mbembe has so effectively illustrated (2001), are often part and parcel of the 'stylistics of power' in African postcolonies?

For Mbembe, the satirical cartoons that attempt to ridicule and thus debase the vulgar excesses of the political elite in Cameroon are 'an integral part of the stylistics of power' (2001: 115), which do not check the power of the 'elite' so much as reinforce their omnipotent presence. Mbembe's argument points the way towards 'recontextualising' rumour 'as a quasi-material substance, as a hinge between the world of concepts and the world of bodily experience' (Weate 2003: 40). In a sense Mbembe does for political anthropology what recent theorising about 'materiality' has done for studies of material culture - exploring the 'mutual imbrication of the semiotic and the material' (Deleuze and Guattari 1987:37).

Rumours, then, like cartoons - and I would argue like bones, bodies and human substances - not only carry or reveal a complexity of meanings; they can have duplicitous political affects. In the same way, we could suggest that the controversies which surrounded the Chibondo exhumations, and challenged ZANU-PF's crude efforts to 'remake' the dead into its own 'liberation heroes', actually also served its interests in another way: by reminding people everywhere of its profound capacity for violence. The significance of this point was recognised by some MDC critics at the time who accused its rival of trying to plant fear in the population that those who don't vote for it will end up dead. ${ }^{33}$

If political authority must always depend upon a combination of legitimacy and sovereignty, then perhaps the 'gross politicking' that surrounded the Chibondo exhumations was not just about reinforcing ZANU-PF's anti-colonialist ideology and legitimacy, but was also a performative exercise in demonstrating (again) that 'the ultimate expression of sovereignty resides ... in the power ... to exercise control over mortality'; what Mbembe calls 'necropolitics' (2003: 11-12). This argument gains strength if we bear in the mind the increasingly troubled politics of the unity government (200913), and particularly the debates already emergent in 2011 about the timing and conduct of future elections. It also provides explanation for the cruder, grotesque dimensions of the politicking taking place at Chibondo - the school visits into the mine and people bussed in from rural areas around the country, broadcast like election jingles on national television. 
Similarly in this perspective the ad hoc, chaotic and decidedly unforensic conduct of the exhumations may have been less about deploying 'African' methods of identifying the dead, or about destroying evidence of ZANU-PF atrocities, than about performative and demonstrative stylistics of power and sovereignty. This view was expressed by some commentators at the time. For example, in responding to reports that the FHT had 'forced school children, teachers and villagers from the surrounding area to view the decomposing remains so that they could "appreciate how evil whites are", the MDC deputy spokesman Chihwayi suggested 'those villagers know that many of those remains are of MDC activists but they are too scared to say it ... that's why ZANU-PF is now instilling fear by showing them those remains. This shows that we are again not going to have free and fair elections. ${ }^{34}$

Perhaps, then, ZANU-PF's interests in the FHT exhumations at Chibondo may have lain not only in reinforcing its message of 'patriotic history'. Importantly, this argument does not rely on the existence of any Machiavellian political intentions to provoke rumours and uncertainty; such political affects can operate regardless of any design. Yet ZANU-PF, or at least some among its turbulent ranks, may have recognised the political purchase of the indeterminate nature of human remains - the torque of human materialities which makes them difficult to read, identify and recognise, and indeed defies such determination even as their emotive and affective qualities demand or insist upon it. It is likely that some in ZANU-PF saw the political usefulness of such uncertainties because it allowed them to have it both ways - to celebrate their 'liberation heroes' and reinforce their anti-colonialist rhetoric, and at the same time, demonstrate and remind Zimbabweans of their own capacities for violence. Furthermore this kind of politics of uncertainty does have some historical purchase in Zimbabwe, and fits an emerging pattern that circulates around the political efficacy of rumours (see Fontein 2009b). This dimension of ZANU-PF politics may be less about controlling narratives of the past than about channelling the indeterminacies of meaning and matter to suit its political purposes.

Yet there is, in the final count, a limit to this argument. If the uncertainties of rumours and material remains are sometimes the site of the reinforcement of a particular mechanism or performance of 'state power', and if rumours that seek to subvert or 'reveal the truth' behind official representations can duplicitously reify the omnipotent presence they seek to undermine, then surely this can work both ways. There always remains the possibility that the 
politics of uncertainty provoked by rumours, and at Chibondo by the indeterminate alterity of human remains, can subvert the other, 'productive aspect of power. This aspect appeals to moral and historical legitimacy, and resonates with people's aspirations to good governance, a functioning state and, in this case, the need to rebury the unsettled dead of the liberation struggle. In 2011, ultimately the uncontained uncertainties about the identities of the dead and the manner of their deaths were not sustainable or easily containable. By August the exhumations had been stopped, the exhumed remains had been reburied and the mineshaft was apparently sealed, amid proclamations that a new national shrine was to be built at the site. The issue disappeared from the news. Perhaps the possibility that some of the remains from the mineshaft at Chibondo might be victims of ZANU-PF's postcolonial atrocities were just too threatening to the legitimacy of its 'patriotic history' project, outweighing any benefits that might have accrued from the grotesque displays of the ability to 'exercise control over mortality' (Mbembe 2003: 11-12). Perhaps, as several people in Harare and Bulawayo suggested, people in the higher echelons of ZANU-PF became concerned that matters at Chibondo had 'got out of hand'. Perhaps, at its simplest, biopolitics outweighed necropolitics. Or as Shari Eppel put it, 'they shut down those exhumations in Mt Darwin ... because their dead scare them' (Fieldnotes, December 2011). In the end, the uncertainties provoked by the torque of human materiality exceeded or overwhelmed its own political utility.

\section{Conclusion}

In 2004 Judith Butler wrote that 'the question that preoccupies me in the light of recent global violence is: Who counts as human? Whose lives count as lives? And finally, what makes for a grievable life?' (Butler 2004: 20). In Zimbabwe these are familiar questions which demand answers that stretch beyond conventional analyses of how postcolonial commemoration is necessarily inflected with the politics of recognition, 'visibility' (Casper and Moore 2009) and the dynamics of inclusion and exclusion. Events at Chibondo illustrate how what Pinney calls the 'alterity of an enfleshed world' (2005: 270) is fundamentally imbricated in the 'disjunctures and fractures' of all human becomings (and unbecomings), in which the politics of commemoration (of 'what makes for a grievable life') are but one dimension. The grisly exhumations at Chibondo in 2011 illustrate how the 
excessive potentiality of human substances demands yet defies any easy 'reading,' 'metaphorisation' or stabilisation, and therefore animates, affords and makes possible the kind of politics of commemoration that Butler refers to. It was, after all, the fleshy, leaky, stinking, maybe still decomposing or otherwise mummified qualities of the many remains being disinterred and reassembled from the Mount Darwin mine that provoked much of the intense debate and criticism the exhumations became enveloped in. Questions about the performative stylistics of power, the politics of uncertainty and contestations over different techniques of determination - of remaking the dead - turn in part on these indeterminate material properties and transformations. And it is the excessive qualities of this human stuff, demanding yet defying easy determination or stabilisation into meaning, which both enabled and exceeded ZANU-PF politicking around the dead, and the multiple, diverse responses that were provoked by it.

\section{Notes}

1 ZANLA was the military wing of ZANU during the liberation war, and ZIPRA the military wing of the older but smaller rival nationalist party, ZAPU. Despite various attempts to combine their efforts, during the war these rivalries sometimes led to fighting between different guerrilla groups, both in Zimbabwe and in guerrilla camps in Mozambique, Zambia and elsewhere.

2 'Mt Darwin's killing fields', Sunday Mail, 13 January 2008; 'Efforts to locate 2nd Chimurenga mass graves continuing', ZBC News, 12 January 2008.

3 A potent example came in January 2008, when, after particularly heavy rains, farmers in Mount Darwin, northern Zimbabwe, reported human bones re-emerging from the soil as they ploughed their fields ('Mt Darwin's killing fields', Sunday Mail, 13 January 2008).

4 Interview, Ambuya VaZarira and VaMoyondizvo, 16 August 2001.

5 '56 war vets reburied', Daily News, 25 October 2001; 'Mysterious deaths rock Kanyemba', Sunday Mail, 3 June 2008.

6 If, as one human rights activist recently explained, during the 1990s many people who directly experienced the terrors of the 1980s were too frightened to 'break the silence' and acquiesced (reluctantly) to government obstruction of any kind of commemoration - so much so, even, that ZANU-PF became 'complacent' - then in the last decade a new generation of 'angry young Ndebele men' has become increasingly vocal (Fieldnotes, 6 December 2011).

7 'We want to know where our loved ones are buried', Letters, Daily News, 3 September 2001; 'Give us money not treatment: Gukurahundi survivors', www.radiovop.com, 23 May 2011; 'Mass graves from Gukurahundi era 
located in Matabeleland', SW Radio Africa, 19 October 2005; 'Evidence of “dirty war” lies far below', Zimbabwe Independent, 29 September 2000; 'Film reveals horror details of Ndebele massacre', Nation (Kenya), 11 November 2007; 'Tracking down a massacre', BBC News, 7 May 2008.

8 According to The Standard, ZANU-PF was 'whipping up people's emotions ahead of an election it dearly wishes to force through this year' ('Sunday Comment: Unearth truth on human remains', The Standard, 26 March 2011). These elections eventually came in July 2013, which ZANU-PF won decisively, amid much controversy and allegations of rigging.

9 See '848 fighters exhumed from Chibondo mineshaft to date', in 'Remember: Chibondo liberation war mass grave exhumations', The Patriot, 30 April 2011 [Supplement].

10 See 'Row over fresh Mt Darwin human remains', The Standard, 20 March 2011.

11 'Skeletons to the rescue', www.thezimbabwemail.com, 23 March 2011.

12 'MDC calls for care, sensitivity in exhumations', www.swradioafrica. com, 24 March 2011.

13 See 'No respect', www.cathybuckle.com, 26 March 2011; 'Sunday Comment: Unearth truth on human remains', The Standard, 26 March 2011.

14 Cox (2005, also Shoko 2006) has discussed the 2004 discovery of 19 mass graves and abandoned mines containing an estimated 5,000 people killed by Rhodesian forces during the 1970s.

15 See for example 'The untold story of Chibondo', in 'Remember: Chibondo liberation war mass grave exhumations', The Patriot, 30 April 2011 [Supplement].

16 'Zimbabwe mass grave becomes political propaganda', Associated Press, 31 March 2011.

17 'ZIPRA veterans challenge chaotic exhumations', www.radiovop.com, 3 April 2011.

18 'Judge halts Mt Darwin exhumations', www.newzimbabwe.com, 7 April 2011.

19 See 'Amnesty: Zim mass grave bodies must be exhumed by experts', Amnesty International Press release, 6 April 2011.

20 'Zimbabwe: Chibondo reburials in progress', The Herald, 13 August 2011.

21 'Row over fresh Mt Darwin human remains', The Standard, 20 March 2011.

22 'Mt Darwin mass graves contain fresh bodies: Pathologist', www.zimdiaspora.com, 27 March 2011; 'Chibondo mass grave cover-up', Zimbabwe Legal Affairs, 4 April 2011.

23 See 'The pain of a historic village', p. 3, in 'Remember: Chibondoliberation war mass grave exhumations', The Patriot, 30 April 2011 [Supplement].

24 Solidarity Peace Trust, 'Hard road to reform', 13 April 2011, p. 48.

25 'ZAPU, MDC demand Gukurahundi exhumations', www.newzimbabwe.com, 19 March 2011; 'Discovered 280 remains not of victims of Rhodesian war: MLF', www.zimdiaspora.com, 19 March 2011. 
26 'ZIPRA veterans challenge exhumations', www.radiovop.com, 3 April 2011; 'Sunday Comment: Unearth truth on human remains', The Standard, 26 March 2011.

27 'Hundred of bodies removed from Zimbabwe mass grave', www.ipsnews. net, 25 March 2011.

28 'Mass graves raise more questions than answers', www.swradio.com, 23 March 2011.

29 Solidarity Peace Trust. Update no. 2, March 2011, 'The silencing of the bones', www.solidaritypeacetrust.org/1015/spt-zimbabwe-update-no-2.

30 See 'Their bones shall rise', in 'Remember: Chibondo liberation war mass grave exhumations', The Patriot, 30 April 2011 [Supplement].

31 www.swradio.com, 23 March 2011.

32 So, for example, the material qualities of corpses at the inherently dangerous, liminal moment of funerals, such as the 'tears' of a corpse or its mouth dropping open, can be 'read' as indicating the frightening temperament of the dead person being buried (Fontein 2010: 437-8).

33 See 'Hundreds of bodies removed from Zimbabwe Mass grave', www. ipsnews.net/, 25 March 2011.

34 See 'Mt Darwin mass graves contain fresh bodies: Pathologist', www. zimdiaspora.com, 27 March 2011.

\section{References}

Alexander, J. J., J. McGregor and T. Ranger, 2000, Violence and Memory. One Hundred Years in the 'Dark Forests' of Matabeleland (Oxford: James Currey).

Bernault, F., 2010, 'Colonial Bones: The 2006 Burial of Savorgnan de Brazza in the Congo', African Affairs 109(436): 367-90.

Bourdillon, M. F. C., 1987 [1976], The Shona Peoples, 3rd edn (Gweru: Mambo Press).

Butler, J., 2004, Precarious Life (London: Verso).

Buyandelgeriyn, M., 2008, 'Post-post-Transition Theories: Walking on Multiple Paths', Annual Review of Anthropology 37: 235-50.

Casper, C. J. and L. Moore, 2009, Missing Bodies: The Politics of Visibility, Biopolitics: Medicine, Technoscience and Health in the 21st Century 1 (New York: New York University Press).

Cox, J. L., 2005, 'The Land Crisis in Zimbabwe: A Case of Religious Intolerance?', Fieldwork in Religion 1(1): 35-48.

Crossland, Z., 2009, 'Of Clues and Signs: The Dead Body and Its Evidential Traces', American Anthropologist 111(1): 69-80.

Daneel, M. (as Mafuranhunzi Gumbo), 1995, Guerrilla Snuff (Harare: Baobab Books).

Deleuze, G. and F. Guattari, 1987 [1980], A Thousand Plateaus, trans. B. Massumi (Minneapolis: University of Minnesota Press).

Domańska, E., 2006, 'The Return to Things', Archaeologia Polona 44: 171-85. 
Eppel, S., 2001, 'Healing the Dead to Transform the Living: Exhumation and Reburial in Zimbabwe', www.solidaritypeacetrust.org/download/essays/ Healing\%20the\%20dead.pdf (accessed 3 February 2010).

Eppel, S., 2004, “Gukurahundi”: The Need for Truth and Reparation', in B. Raftopoulos and T. Savage (eds), Zimbabwe: Injustice and Political Reconciliation, pp. 43-62 (Harare: Weaver Press).

Eppel, S., 2009, 'A Tale of Three Dinner Plates: Truth and the Challenges of Human Rights Research in Zimbabwe', Journal of Southern African Studies 35(4): 966-76.

Filippucci, P., 2010, 'Archaeology and Memory on the Western Front', in D. Boric (ed.), Archaeology and Memory, pp. 171-82 (Oxford: Oxbow Books).

Filippucci, P., J. Harries, J. Fontein and K. Krmpotich, 2012, 'Encountering the Past: Unearthing Remnants of Humans in Archaeology and Anthropology', in D. Shankland (ed.), Archaeology and Anthropology: Past, Present and Future, ASA Monographs 48, pp. 197-218 (London: Berg).

Fontein J., 2009a, 'The Politics of the Dead: Living Heritage, Bones and Commemoration in Zimbabwe', ASAonline 1/2, www.theasa.org/publications/asaonline/articles/asaonline_0102.htm (accessed 27 March 2014).

Fontein, J., 2009b, 'Anticipating the Tsunami: Rumours, Planning and the Arbitrary State in Zimbabwe', Africa 79(3): 369-98.

Fontein, J., 2010, 'Between Tortured Bodies and Resurfacing Bones: The Politics of the Dead in Zimbabwe', Journal of Material Culture 15(4): 423-48.

Fontein, J., 2011, 'Graves, Ruins and Belonging: Towards an Anthropology of Proximity', Journal of the Royal Anthropological Institute 17: 706-27.

Fontein, J. and J. Harries, 2009, 'Report of the "Bones Collective" Workshop, 4-5 December 2008: What Lies Beneath: Exploring the Affective Presence and Emotive Materiality of Human Bones', www.san.ed.ac. uk/_data/assets/pdf_file/0013/29110/Final_Report.pdf (accessed 3 February 2010).

Gell, A., 1998, Art and Agency. An Anthropological Theory (Oxford: Oxford University Press).

Hallam, E., 2010, 'Articulating Bones: An Epilogue', Journal of Material Culture 15(4): 465-92. Special Issue: The Substance of Bones: The Emotive Materiality and Affective Presence of Human Remains.

Henare, A., M. Holbraad and S. Wastell, 2007, 'Introduction', in A. Henare, M. Holbraad and S. Wastell (eds), Thinking through Things, pp. 1-31 (London: Routledge).

Hertz, R., 1960, Death and the Right Hand, trans. R. Needham and C. Needham (New York: Free Press).

Ingold, T., 2007, 'Materials against Materiality', Archaeological Dialogues 14(1): 1-16.

Ingold, T., 2009, 'The Textility of Making', Cambridge Journal of Economics 34(1): 91-102.

Jindra, M. and J. Noret (eds), 2011, Funerals in Africa: Explorations of a Social Phenomenon (London: Berghahn Books). 
Kriger, N., 1995, 'The Politics of Creating National Heroes', in N. Bhebe and T. Ranger (eds), Soldiers in Zimbabwe's Liberation War, pp. 139-62 (London: James Currey).

Krmpotich, C., J. Fontein and J. Harries, 2010, 'Preface', Journal of Material Culture 15(4): 371-84. Special Issue: The Substance of Bones: The Emotive Materiality and Affective Presence of Human Remains.

Kuchler, S., 1999, 'The Place of Memory', in A. Forty and S. Kuchler, S. (eds), The Art of Forgetting, pp. 53-72 (Oxford: Berg).

Latour, B., 1999, Pandora's Hope: An Essay on the Reality of Science Studies (Cambridge, MA: Harvard University Press).

Leach, J., 2007, 'Differentiation and Encompassment: A Critique of Alfred Gell's Theory of the Abduction of Creativity', in A. Henare, M. Holbraad and S. Wastell (eds), Thinking through Things, pp. 167-88 (London: Routledge).

Lee, R. and M. Vaughan, 2008, 'Death and Dying in the History of Africa since 1800', Journal of African History 49(3): 341-59. Special Issue: Death in African History.

Masunungure, E. (ed.), 2009, Defying the Winds of Change: Zimbabwe's 2008 Elections (Harare: Weaver Press).

Mbembe, A., 2001, On the Postcolony (Berkeley and London: University of California Press).

Mbembe, A., 2003, 'Necropolitics', Public Culture 15(1): 11-40.

Miller, D. (ed.), 2005, Materiality (Durham, NC and London: Duke University Press).

Muchemwa, K. Z., 2010, 'Necropolitan Imagination', Social Dynamics 36(8): 504-14.

Navaro-Yashin, Y., 2009, 'Affective Spaces, Melancholic Objects: Ruination and the Production of Anthropological Knowledge', Journal of the Royal Anthropological Institute 15: 1-18.

Pinney, C., 2005, 'Things Happen: Or, from Which Moment Does That Object Come?', in D. Miller (ed.), Materiality, pp. 256-72 (Durham, NC and London: Duke University Press).

Posel, D. and P. Gupta, 2009, 'The Life of the Corpse', African Studies 68(3): 299-309.

Ranger, T., 1999, Voices from the Rocks: Nature, Culture and History in the Matopos Hills of Zimbabwe (Oxford: James Currey).

Ranger, T., 2004, 'Historiography, Patriotic History and the History of the Nation: The Struggle over the Past in Zimbabwe', Journal of Southern African Studies 30(2): 215-34.

Renshaw, L., 2010, 'Scientific and Affective Identification of Republican Civilian Victims from the Spanish Civil War', Journal of Material Culture 15(4): 449-63. Special Issue: The Substance of Bones: The Emotive Materiality and Affective Presence of Human Remains.

Rowlands, M., 1999, 'Remembering to Forget: Sublimation as Sacrifice in War Memorials', in A. Forty and S. Kuchler (eds), The Art of Forgetting, pp. 129-45 (Oxford: Berg).

Shoko, T., 2006, “My Bones Shall Rise Again”: War Veterans, Spirits and Land Reform in Zimbabwe', ASC Working Paper 68 (Leiden: African Studies Centre). 
Solidarity Peace Trust (SPT), 2008a, 'Punishing Dissent, Silencing Citizens: The Zimbabwe Elections 2008', 21 May 2008, Johannesburg, www.solidaritypeacetrust.org/index.php?page=reports (accessed 3 February 2010).

Solidarity Peace Trust (SPT), 2008b, 'Desperately Seeking Sanity: What Prospects for a New Beginning in Zimbabwe?', 29 July 2008, Durban, www.solidaritypeacetrust.org/index.php?page=reports (accessed 3 February 2010).

Tendi, B.-M., 2010, Making History in Mugabe's Zimbabwe: Politics, Intellectuals and the Media (Oxford: Peter Lang).

Verdery, K., 1999, The Political Lives of Dead Bodies: Reburial and Postsocialist Change (New York: Columbia University Press).

Weate, J., 2003, 'Achille Mbembe and the Postcolony: Going beyond the Text', Research in African Literatures 34(4): 27-41.

Werbner, R., 1991, Tears of the Dead: The Social Biography of an African Family (Edinburgh: Edinburgh University Press).

Werbner, R., 1998, 'Smoke from the Barrel of a Gun', in R. Werbner (ed.), Memory and the Postcolony: African Anthropology and the Critique of Power, pp. 71-103 (London: Zed Books). 